\title{
Estimation of Genetic Variance and Broad Sense Heritability of Sugar Cane (Saccharum Spp. L.)
}

\author{
Yusria H. Tawfik, A.H.S. Al-Labbody and S.R.E. El-Sheik ${ }^{1}$
}

\begin{abstract}
The present investigation was carried out at the Sabahia Agricultural Research Station; Alexandria, Egypt as planted crop in the two spring seasons 2004/2005, 2005/2006, on ten sugar cane varieties. The objectives of this study were to determine means, ranges, coefficient of variability, variance components and broad sense heritability for some important characters in a population of ten sugar cane varieties. The studied characters are stalk length; stalk diameter, number of internodes, stalk weight, total soluble solid \% (Brix), sucrose \% and purity \%. The ten varieties used in the present study were obtained from different countries. They were used as parents of the important varieties and as promising Egyptian ones. These varieties are Co.312, Co.421, from India; CP.44-101 from U.S.A., N.Co.310, from South Africa; Ph. 8013, from Philippine; and G.74-96, G.75-368, G.84-47, G.85-37, G.T.54-9, from Egypt. The variety Co.312 was one of the two parents of NCo.310, which had been used as pistil parent for G.T.54-9, G.85-37, G.84-47, G.74-96 and G.75368. The variety, Cp.44-101, has been used as male parent of G.75-368. Highly significant differences were recorded for the tested varieties in all examined traits. The results indicated that, G.T.54-9, Ph.8013, G.85-37, G.75-368, varieties gave a good performance for the studied characters over both seasons. The studied estimates of coefficient of variability, genotype and phenotype were proven to be less than $10 \%$ for all studied characters except for the stalk weight. The genetic variance calculated for the different characters was essential in determining the phenotypic variance, which ranged from 0.0513 for stalk diameter to 8775.39 for stalk weight. The genetic variance for all studied characters was higher than that the environmental variance. Broad sense heritability estimates for sucrose percent was the largest one it recorded $(96 \%)$, followed by stalk length $(95 \%)$, stalk weight $(94 \%)$, total soluble solids percent ( $93 \%)$, number of internodes $(92 \%)$, purity present $(89 \%)$ and stalk diameter $(88 \%)$. This study suggests that genetic variance was the largest source of total variation for studied characters; therefore, the improvement of cane varieties will have more genetic progress and more effective through the seven studied characters. This result indicates that a significant improvement of stalk weight for new lines of sugar cane could be achieved. The chance would be capable to raise sugar cane varieties with good characters.
\end{abstract}

\footnotetext{
${ }^{1}$ Breeding Genetic Department, Sugar Crops

Research Institute, Agricultural Research Center, Giza, Egypt

Received April 30.2008.Accepted. June 22.2008
}

\section{INTRODUCTION}

Sugar cane flowering is highly affected by environmental conditions more than by genetic factors. In Egypt, specially after the success of sugar cane flowering naturally in Sabahia, Alexandria, Rao et al. (1973), this has facilitated breeding and developing sugar cane varieties through crossing methods, and evaluation the delivered clones in upper Egypt, where commercial sugar cane is produced.

Heritability in a broad sense is meaningful, in asexually propagated crops such as sugar cane, since all genetic variability is usable between asexual generations of selection. Estimating the heritability provides a measure of the effectiveness with which selection can be expected to exploit the genetic variability. Many quantitative inheritance studies have been conducted recently in order to obtain information on the inheritance of the important characters of sugar cane. Allam et al(1977) reported that a highly significant difference among clones was noted for cane yield and sugar yield, within all three cane types (plant, first-stubble and second-stubble).They reported that heritability estimates were $(0.78,0.83,0.75)$ for plant cane, $(0.87,0.86,0.82)$ for first- stubble, and $(0.90,0.89,0.87)$ for second stubble. The heritability estimates were increased from type to type cane for all traits. Their high heritability values are of particular interest to the sugar cane breeder as they estimate the latitude for gain through selection. Although the total genetic variance component may contain dominance and epistatic effects, the expected gain from selection based on a broad sense heritability estimate should be appropriate since sugar cane is asexually propagated. Singh and Singh (1981) stimated high heritability for number of internodes per stem, height, number of green leaves per stem and Brix. Kang et al. (1983) estimated high broad sense heritability in two biparental crosses for various traits which were $84 \%$ for plant height, $94 \%$ for stalk diameter, $93 \%$ for stalk weight, and $91 \%$ for sucrose content. El Manhaly et al (1987), studied sugar cane flowering and seed setting under Alexandria condition. He reported that the flowering percentage varied between and within varieties from less than $40 \%$ to more than $70 \%$. Milligan et al. (1990), mentioned that the phenotypic variance was similar to error variance for stalk weight in plant 
crop and the estimates of stalk weight heritability was among the largest observed of all traits. However, the heritability of sucrose concentration and Brix was relatively high. Chang (1996) estimated $0.955,0.944$ and 0.965 broad sense heritability for Brix, purity and sugar content, respectively. Chang (1997) found that the broad sense heritability of Brix is similar to that of sugar content during the whole maturity stages. Younan et al (1997) found that the broad sense heritability ranged from $61.3 \%$ for number of green leaves to $85.32 \%$ for number of internodes. The genetic variance calculated for the different characters was essential in determining the phenotypic variance, which ranged from 0.0148 for stalk weight to 123.626 for stalk length. The variance due to the interaction of genotype $\mathrm{X}$ environment was secondary to genetic variance, while the error variance which refers to the environmental variance was the smallest part of the phenotypic variance. El Taib et al (2005)evaluated some selected genotypes of sugar cane. They found significant differences between environment and genotype interaction for stalk weight, number of millable cane, net cane yield ( $\mathrm{t} / \mathrm{fed}$ ), theoretical sugar recovery $\%$, and sugar yield (t/fed). Ghura (2005) found that the broad sense hertability ranged from $90 \%$ for stalk diameter and sucrose percent to $78 \%$ for purity percent. The genetic variance ranged from 0.209 for stalk diameter to 93.51 for stalk length. The genotypic coefficient of variability (GCV \%)for the studied characters ranged from $9.27 \%$ calculated for total soluble solids percent (Brix) to $32.7 \%$ for stalk weight. The phenotypic coefficient of variability (PCV $\%$ )ranged from $10.02 \%$ to $35.14 \%$ for total soluble solids percent (Brix) and stalk weight respectively.

The objectives of this work were to estimate genetic and environmental variance components for some important characters of sugar cane, to determine the relative importance of genetic and environmental variances in influencing the phenotypic variance, and to estimate broad sense heritability for some important characters of ten sugar cane varieties to produce seed setting every year and have been used as parents in the breeding program.

\section{MATERIALS AND METHODS}

The present investigation was carried out at the Sabahia Agricultural Research Station; Alexandria, Egypt as planted crop in the two spring seasons $2004 / 2005,2005 / 2006$, on ten sugar cane varieties used to reach complete flowering at Sabahia area during the last twenty years. They are characterized with high cane stalk weight, good thickness, tall and high sugar content. Because of their good characteristics, they have been chosen to be as start for breeding programs for developing promised sugar cane varieties for Egypt and other similar countries.

A randomized complete block design with four replications in a factorial experiment was used in this study. Cuttings of the ten varieties were planted at the end of march and the beginning of April of the two seasons respectively, as spring planting. Each variety was sown in plots containing 7 ridges 1.5 meter in width and 5 meters in length. The distance between cuttings was $30 \mathrm{~cm}$. Each cutting contained two buds. The plot area was $52.5 \mathrm{~m} 2(10.5 \mathrm{~m} \times 5.0 \mathrm{~m})$. All recommended agricultural practices needed for growing sugar cane crop were applied in both seasons. In each season, harvest took place ten months after planting. Thirty plants were randomly taken from each plot to study the following characters: stalk length, stalk diameter, number of internodes, stalk weight, total soluble solid \% (Brix), sucrose $\%$ and purity $\%$.

Analysis of variance components was performed for each character. Variance components were calculated by equating appropriate mean squares to their expectation, according to Steel and Torrie (1980). The treatment means were compared by using the least significant differences (L.S.D.) test by Waller and Duncan, 1969 at 5\% and 1\% levels of probability. The homogeneity tests of error variances of both seasons indicated that error terms were homogenous then the combined analysis was used for the traits measured at both seasons. Broad sense heirtability (h2) estimates were calculated on a plots mean, according to Hogarth (1977), with the formula:

$\mathrm{h}^{2}=\sigma^{2} \mathrm{~g} / \sigma^{2} \mathrm{ph}$

Where:

$\sigma^{2} \mathrm{~g}=$ the genetic variance was calculated from the formula

$$
=\frac{M S_{\mathrm{V}}-\mathrm{MS}_{\mathrm{Vy}}}{\text { r.y }}
$$

$\sigma^{2} \mathrm{ph}=$ the phenotypic variance $=\sigma^{2} \mathrm{~g}+\sigma^{2} \mathrm{~g} \mathrm{y}+\sigma^{2} \mathrm{e} / \mathrm{ry}$

Where:

$\mathrm{MS}_{\mathrm{v}} \quad=$ the mean square of the varieties

$\mathrm{MS}_{\mathrm{vxy}}=$ variance due to interaction of variety $\mathrm{X}$ year.

$\sigma^{2} \mathrm{~g}$ y $\left\{\begin{array}{c}=\text { The mean squares of the interaction } \\ \quad \text { of varieties and years. } \\ =\left(\mathrm{MS}_{\mathrm{vy}}-\mathrm{MS}_{\mathrm{e}}\right) / \mathrm{r}\end{array}\right.$

$\mathrm{R}=$ number of replicates

$\mathrm{Y} \quad=$ number of years

$\sigma^{2} \mathrm{e}=$ the error variance

The components $\sigma^{2} \mathrm{ph}$ and $\sigma^{2} \mathrm{~g}$ are used for estimation of other statistics such as :- 
Phenotypic coefficient of variation (P.C.V.) =

$$
\frac{\sqrt{\sigma^{2} p h}}{x^{-}} \times 100
$$

Genotypic coefficient of variation (G.C.V.) =

$$
\frac{\sqrt{\sigma^{2} g}}{X^{-}} x 100
$$

\section{RESULTS AND DISCUSSION}

Analysis of variance for the seven studied quantitative characters (stalk length, stalk diameter, number of internodes, stalk weight, total soluble solids, sucrose percentage and purity percentage) for the ten tested sugar cane varieties are presented in Table(1). Highly significant differences were noticed for the tested varieties in all examined traits. With regard to the interaction between varieties and years, highly significant differences were found for stalk length, stalk weight, total soluble solids, sucrose percentage and purity percentage, significant differences was found for number of internodes, no significant differences in stalk diameter had achieved. Mean values for different characters of ten sugar cane varieties for the two seasons are presented in Table(2). The data show that, G.T. 54-9 variety had the highest values in stalk length, stalk diameter, stalk weight and total soluble solids percentage. Ph.8013, variety had the highest values in number of internodes, sucrose percentage and purity percentage. These increased values have no significance, compared to G.T.54-9 variety. While, CP.44101 variety had the lowest values in stalk weight, total soluble solids percentage, sucrose percentage and purity percentage. Varieties X year's interactions were apparent in the rankings of the varieties in the two examined years. The evaluation of the studied varieties indicated that G.T. 54- 9, Ph. 8013, G.85-37, and G.75-368 varieties gave a good performance for the seven studied characters over both seasons.

Means, ranges, coefficients of variability percent (genotypic and phenotypic), variance components (genotypic and phenotypic), and broad sense heritability for the seven studied characters, of a population of ten varieties of sugar cane are tabulated in table(3). As shown from this table considerable variations in range among varieties are found. The values of stalk length ranged from 205.75 to $299.75 \mathrm{~cm}$., with mean value equal to $231.97 \mathrm{~cm}$. The value of stalk diameter ranged from 3.17 to $5.16 \mathrm{~cm}$, with mean value $=3.83 \mathrm{~cm}$. The value of number of internodes ranged from 11.14 to 16.46 nodes, with mean value $=14.01$ nods. The range and mean of stalk weight (g.) ranged from 433.5 to 939.5 with mean value $=734.6 \mathrm{~g}$. The values of $($ T.S.S.
$\%$ ) and sucrose (\%) ranged from $17.8 \%$ to $21.83 \%$ and 12.24 to $15.28 \%$ with mean value equal $20.10 \%$ and $14.1 \%$ respectively. The values of purity $(\%)$ ranged from $64.59 \%$ to $79.73 \%$ with mean value equal $73.4 \%$. The studied results for coefficient of variability percent (genotypic and phenotypic) were less than $10 \%$, for all characters, except for the stalk weight. On the other side, variance components and broad sense heritability for the seven studied characters are shown in the same table. As shown in this table the genetic variance for all studied character was higher than the environment and the interaction variances. So when estimated broad sense heritability for sucrose percent was the largest one it recorded (96\%), followed by stalk length $(95 \%)$, stalk weight (94\%), total soluble solids (93\%), number of internodes (92\%), purity percent (89\%), and stalk diameter (88\%). This is due to the high genetic variance obtained for the seven characters compared to the other two variances. This study suggested that genetic variance was the largest source of total variation for studied characters. These results are in good agreement with those reported by several authors (e.g. Gaber et al 1990; Tawfic et al 1997; Younan et al 1997, Ghura 2005 and Saleh et al 2006). Therefore, the improvement of cane varieties will have more genetic progress and more effective through the seven studied characters.This result indicated that a significant improvement for new lines could be achieved, and the chance will be to raise new varieties of sugar cane clones in Egypt characterised with good characters.

\section{ACKNOWLEDGMENTS}

The authors would like to thank Prof. Dr.M.M. ELRouby, Professor of Crop Science and Statistics, Field Crop Department College of Agriculture (ElShatby), Alexandria University, for his statistical advice and invaluable criticism.

\section{RE FERENCES}

Allam, A.I., A.H.Nour and T.A.Fayed.(1977). The flowering behavior of latitudinally displaced sugar cane varieties. Proc. Int.Soc.Sug. cane.Tech. XVI:283-290.

Chang, Y.S. (1996). Estimating hertability of and correlation among Brix, Purity, and sugar content in sugar cane using balanced multiple location and year data. Rep. Taiwan Sugar Res. Inst. 151: 1-10.

Chang, Y.S. (1997). Estimating hertabiliy of and correlation among Brix, Purity, and sugar content in sugar cane using balanced multiple location and year data. Rep. Taiwan sugar Res. Inst. 44: $18-22$.

El-Manhaly, M.A.; M.F. Maareg, A.A. Gaber and A.Farage.(1987). 
Sugarcane flowering and seed setting .Alex.Sci. Exch. 8(2):129-139 .

El-Taib,A.B.A; M.Z.El-Hifny;E.E.S. Mahdy and A.M. Abou-Salama (2005). Performance of some selected sugar cane genotypes in two Upper Egypt locations. International Conference on: Political, Economic and Technological challenges for sugar and its

Intergrated Industries in the Arab Region, the Middle East, Africa and the European union" 306 April 2005, Alex, Egypt poster No, 6.

Gaber, A.A., M.F. Abou El-Fath and A.H.Nour.(1992).Flowering behavior of some sugarcane varieties at Alexandria. Egypt. Alex. Sci. Exch.13(4):831844.

Ghura, Nabawya S.A. 2005. Heritability in sugar cane (Saccharum officinarum L.) Alx. Sci Exchange Journal. Vol. 26, No. 4,396-404.

Hogarth, D. M.(1977) Quantitative inheritance studies in sugarcane III. The effect of competition and violation of genetic assumptions on estimation of genetic variance components. Aust. J. Agric. Res . 28:257-268

Kang, M. S.; j. D Miller and P.Y.P. Taï (1983).Genetic and phenotypic path analysis and heritability in sugar cane Crop Sci. 23: 643-647.

Milligan, S.B.; K.A.Gravois, K.P.Bischoff and F.A.Martin (1990). Crop effects on broad sense heritabilities and genetic variance of sugar cane yield components. Crop Sci 30:344-349.

Rao, J.T., A.H. Nour and M.A. El-Manhaly (1973). Flowering of sugar cane in Egypt. Int. Sugar Journal, 75:241-244.

Saleh, M.S., Nabawaya S.A, Gura and M.A.El-Manhaly (2006) Genetic Diversity of forty sugar cane (Saccharum officinarum L.) varieties based on quantitative traits and isoperoxidase activity. Alex. J.Agric.Res.51 (1) 37-53.

Singh, H. N.; T.K. Singh (1981). Selection parameters in sugar cane. Indian. Journal of Agricultural Sciences. 51(8): 562-566 (En, 13 ref.) up counc. Sugar Cane Res. Shahjahanpur, U.P. India.

Steel, R.G. and J.H. Torrie.(1980) Principles and procedures of statistics. A biometrical approach McGraw - Hill 4th printing.

Tawfik, Yusria Hanem, M.Z. Attalah,Nabawya S.A. Ghura and M.N.El-Deep.(1997). Control of flowering in sugarcane by nitrogen application after initiation stage in Egypt. J. Agic. Sci.22 (5): 1763-1771. Mansoura Univ.Egypt.

Waller, R.A. and D.B. Duncan (1969). Aboy's rule for the symmetric multiple comparison problem, Am. Assoc. J. Dec. 1496-1503.

Younan, N.Z.; M.A.El-Deeb and N.M.EL.Talkhawy (1997).

Estimation of genetic variance and broad sense heritability for some characters of sugar cane (Saccharum officinarum L.). Adv. Agric. Res. Vol. 2, No.1. 


\section{الملخص العربي \\ تقدير التباين الوراثى ومعامل التوريث بالمعنى الواسع لنبات قصب السكر}

$$
\text { يسرية هانم توفيق، اشرف حنفى سيد اللبودى، صلاح رفاعى إمام الشيخ }
$$

تايسوان54-9 والصــف الفلبيسنى 8013 والاصسناف المصـرية جيـزة

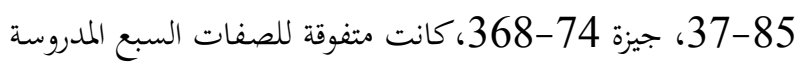

$$
\text { خلال موسمى الزراعة. }
$$

وقد اظهرت الدراسة ان معامل الاختلاف الوراثى والمظهرى كانا اقل من10\%وذلك لجميع الصفات المدروسة ماعدا صفة وزن العود. عند تقدير التباين الوراثى والمظهرى للصفات المدروسة فقد كانت

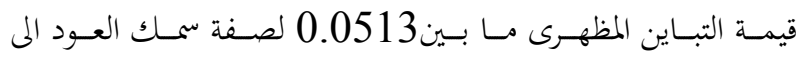

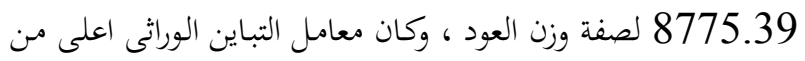

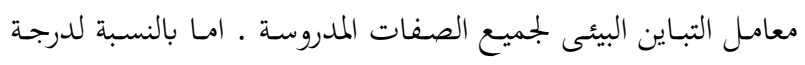

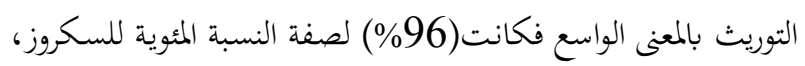

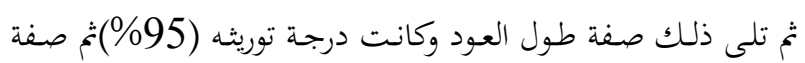
وزن العود كانت درجة توريثه (94\%)، ثم صفة دول النسبة المئوية للمواد

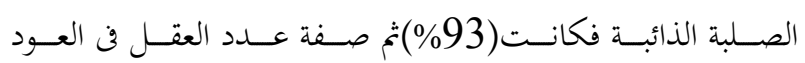

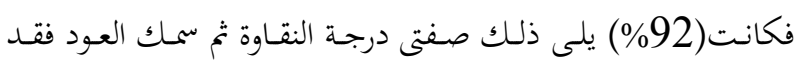
سجلا نسبة ( 89\%)، (88\%) (على التوالى. ومن هذا يتضح ان معامل التوريث للصفات تحت هذه الدراسة

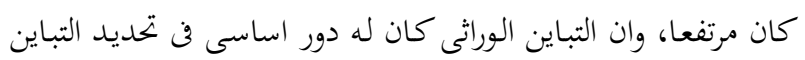

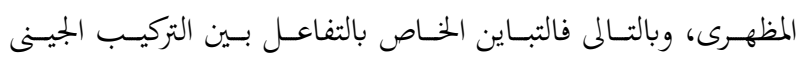
والظروف البيئية كان ثانويا لمعظم الصفات تحت الدراسة. وعليه فانه

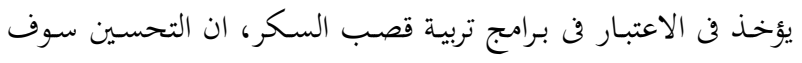

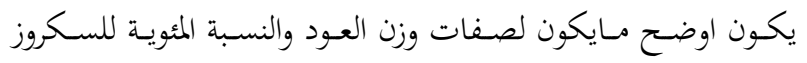

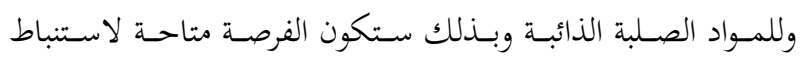

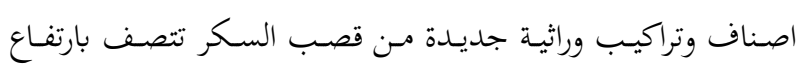
المحصول تحت الظروف المصرية.
اجريست هـذه الدراسـة في مطــة البحــوث الزراعيـة بالصـبحية

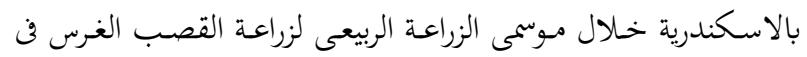

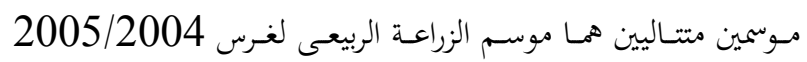
وموسم الزراعة الربيعى لغرس 2006/2005. الهدف من اجراء هذا البحث هو تقدير بعض المقاييس والثوابت

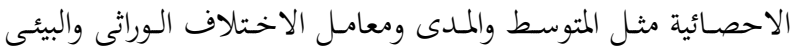

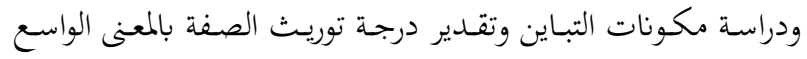

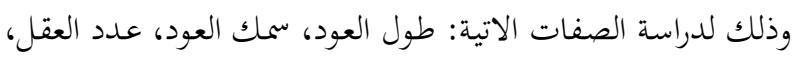

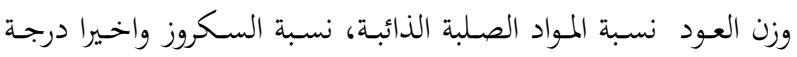

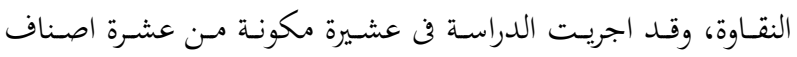

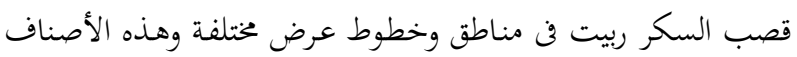
تمثل اصناف تجارية او اباء تربية. مـن هذه الاصناف كوامبـ

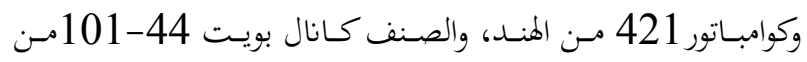

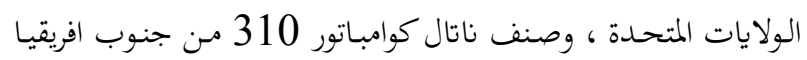
والصنف الفلبينى 8013 امـا الاصناف الخمسـة التالية تم استنباطها

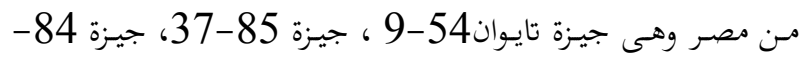

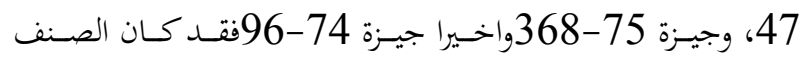
كوامبـاتور 312 احسد اباء الصـنف التجـارى، ناتال كوامبـاتور 310 وهذا الاخير هو الاب المؤنث للاصناف المصرية جيزة تايوان 54-9

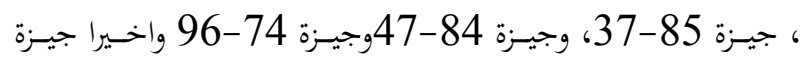

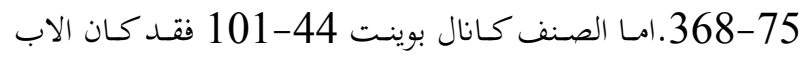

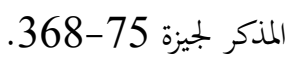

اوضحت النتائج وجود اختلافات عالية المعنوية في جميع التجارب التى اجريت وقد اظهرت النتائج ان الاصناف جيزة 